Available online at http://jiddtonline.info RESEARCHARTICLE

\title{
STABILITY INDICATING LIQUID CHROMATOGRAPHIC METHOD FOR THE QUANTITATIVE DETERMINATION OF VALGANCICLOVIR IN PHARMACEUTICAL DOSAGE FORMS
}

\author{
M. Mathrusri Annapurna*, K. Lakshmi Sai Tulasi and M. Sirichandra \\ Department of Pharmaceutical Analysis \& Quality Assurance, \\ GITAM Institute of Pharmacy, GITAM University, Visakhapatnam-530045, India \\ *Corresponding author's E mail: mathrusri2000@yahoo.com Tel:91-9985654603
}

\begin{abstract}
A selective, specific and sensitive stability-indicating high-performance liquid chromatographic method was developed and validated for the determination of Valganciclovir in tablet dosage forms. Reversed-phase chromatography was performed on Shimadzu Model CBM-20A/20 Alite, equipped with SPD M20A prominence photodiode array detector (Isocratic mode) using C18 column $(250 \mathrm{~mm} \times 4.6 \mathrm{~mm}, 5 \mu \mathrm{m})$ with a flow rate of $0.8 \mathrm{~mL} / \mathrm{min}$. UV detection was carried at $254 \mathrm{~nm}$. Linearity was observed in the concentration range of $1.0-200 \mu \mathrm{g} / \mathrm{mL}$ with regression equation $\mathrm{y}=50968 \mathrm{x}+86374$ with correlation coefficient of 0.999 . The LOQ and LOD were found to be $0.8641 \mu \mathrm{g} / \mathrm{mL}$ and $0.2813 \mu \mathrm{g} / \mathrm{mL}$ respectively. Valganciclovir was subjected to stress conditions such as acidic, alkaline, oxidation, photolysis and thermal degradations. The developed method was validated as per ICH guidelines and it can be applied for the determination of Valganciclovir in pharmaceutical dosage forms.
\end{abstract}

Keywords: Valganciclovir, Isocratic mode, RP-HPLC, Validation, Stability-indicating, LOD, LOQ.

\section{INTRODUCTION}

Valganciclovir $\mathrm{HCl}$ (VGC), chemically L-Valine, 2[(2amino-1,6-dihydro-6-oxo-9H-purin-9-yl)methoxy]-3hydroxypropyl ester, monohydrochloride. (Figure 1) is a white to off-white crystalline powder with a molecular formula of $\mathrm{C}_{14} \mathrm{H}_{22} \mathrm{~N}_{6} \mathrm{O}_{5} \cdot \mathrm{HCl}$ and a molecular weight of 390.83 It is an antiviral medication used to treat cytomegalovirus infections. As the L-valyl ester of ganciclovir, it is actually a prodrug for ganciclovir. After oral administration, it is rapidly converted to ganciclovir by intestinal and hepatic esterases. The mechanism of action of Valganciclovir is that it is a prodrug of ganciclovir that exists as a mixture of two diastereomers. After administration, these diastereomers are rapidly converted to ganciclovir by hepatic and intestinal esterases. In cytomegalovirus infected cells, ganciclovir is initially phosphorylated to the monophosphate form by viral protein kinase, then it is further phosphorylated via cellular kinases to produce the triphosphate form. This triphosphate form is slowly. Very few methods are reported in the literature including liquid chromatographic methods $^{2-4}$, spectrophotometric techniques ${ }^{5}$ and LC/MS/MS ${ }^{6-8}$ methods for the determination of Valganciclovir in tablet dosage forms and in biological fluids. Suresh Kumar et al., have studied the Impurity profile and related substances ${ }^{9}$ of Valganciclovir and Stefanidis et al., studied the reactivity ${ }^{10}$ of Valganciclovir in aqueous solution. In the present work the authors have proposed a simple, rapid, robust, precise and accurate reverse phase liquid chromatographic method for the determination of Valganciclovir in tablet dosage forms.

\section{MATERIALS AND METHODS}

\section{Chemicals and Reagents}

Valganciclovir standard (purity $\geq 99.98 \%$ ) was obtained from Roche, India. Methanol (HPLC grade), sodium hydroxide and hydrochloric acid, Glacial acetic acid and hydrogen peroxide were purchased from Merck (India).

Valganciclovir is available as tablets with brand name VALCYT $^{\circledR}$ as tablets (Label claim: $450 \mathrm{mg}$ ). All chemicals were of analytical grade and used as received.<smiles>CC(Cl)C(N)C(=O)OC[C@H](CO)OCn1cnc2c(=O)[nH]c(N)nc21</smiles>

Figure 1: Chemical structure of Valganciclovir (VGC)

\section{Instrumentation and Chromatographic Conditions}

Chromatographic separation was achieved by using a Shimadzu Model CBM-20A/20 Alite HPLC system, equipped with SPD M20A prominence photodiode array detector $(250 \mathrm{~mm} \times 4.6 \mathrm{~mm}, 5 \mu \mathrm{m}$ particle size $)$ maintained at $25^{\circ} \mathrm{C}$. Isocratic elution was performed using a mixture of methanol, water and glacial acetic acid $(45: 55: 0.1, \mathrm{v} / \mathrm{v})$ with flow rate $0.8 \mathrm{~mL} / \mathrm{min} .20 \mu \mathrm{L}$ of each solutions were injected into the HPLC system.

\section{Preparation of Valganciclovir Stock Solution}

Valganciclovir stock solution $(1000 \mu \mathrm{g} / \mathrm{mL})$ was prepared by accurately weighing $25 \mathrm{mg}$ of Valganciclovir in a 25 $\mathrm{mL}$ amber volumetric flask and making up to volume with mobile phase. Working solutions for HPLC injections were prepared from the stock solution mobile phase. Solutions were filtered through a $0.45 \mu \mathrm{m}$ membrane filter prior to injection.

\section{Assay of marketed formulations}

ISSN: 2250-1177 
Twenty tablets from each brand $\left(\mathrm{VALCYT}^{\circledR}\right.$ ) were procured, weighed and crushed to a fine powder. Powder equivalent to $25 \mathrm{mg}$ Valganciclovir was accurately weighed into a $25 \mathrm{ml}$ volumetric flask and made up to volume with mobile phase. The contents of the volumetric flask were sonicated for $30 \mathrm{~min}$ to enable complete dissolution of Valganciclovir. The solution was filtered and the filtrate was diluted with mobile phase. $20 \mu \mathrm{L}$ of these solutions were injected into the system and the peak area was recorded from the respective chromatogram.

\section{Forced Degradation Studies/Specificity}

Forced degradation studies were performed to evaluate the stability indicating properties and specificity of the method 11. All solutions for use in stress studies were prepared at an initial concentration of $1 \mathrm{mg} / \mathrm{mL}$ of Valganciclovir and refluxed for $30 \mathrm{~min}$ at $80^{\circ} \mathrm{C}$. All samples were then diluted in mobile phase to give a final concentration of $100 \mu \mathrm{g} / \mathrm{mL}$ and filtered before injection.

\section{Acidic and Alkaline Degradation}

Acid decomposition was carried out in $0.1 \mathrm{M} \mathrm{HCl}$ at a concentration of $1.0 \mathrm{mg} / \mathrm{mL}$ Valganciclovir and after refluxation for $30 \mathrm{~min}$ at $80{ }^{\circ} \mathrm{C}$ the stressed sample was cooled, neutralized and diluted with mobile phase to give a final concentration of $100 \mu \mathrm{g} / \mathrm{mL}$ and filtered before injection. Similarly stress studies in alkaline conditions were conducted using a concentration of $1.0 \mathrm{mg} / \mathrm{mL}$ in 0.1 $\mathrm{M} \mathrm{NaOH}$ and refluxed for $30 \mathrm{~min}$ at $100{ }^{\circ} \mathrm{C}$. After cooling the solution was neutralized and diluted with mobile phase to give a final concentration of $100 \mu \mathrm{g} / \mathrm{mL}$ and filtered before injection.

\section{Oxidative Degradation}

Solutions for oxidative stress studies were prepared using $3 \% \mathrm{H}_{2} \mathrm{O}_{2}$ at a concentration of $1 \mathrm{mg} / \mathrm{mL}$ of Valganciclovir and after refluxation for $30 \mathrm{~min}$ at $100{ }^{\circ} \mathrm{C}$ on the thermostat the sample solution was cooled and diluted with the mobile phase to give a final concentration of 100 $\mu \mathrm{g} / \mathrm{mL}$ and filtered before injection.

\section{Thermal Degradation}

For thermal stress testing, the drug solution $(1 \mathrm{mg} / \mathrm{mL})$ was heated in thermostat at $100{ }^{\circ} \mathrm{C}$ for $30 \mathrm{~min}$, cooled and diluted with the mobile phase to give a final concentration of $100 \mu \mathrm{g} / \mathrm{mL}$ and filtered before injection.

\section{Method Validation}

The method was validated for the following parameters: system suitability, linearity, limit of quantitation (LOQ), limit of detection (LOD), precision, accuracy, selectivity and robustness ${ }^{12}$.

\section{Linearity}

Linearity test solutions for the assay method were prepared from a stock solution at different concentration levels of the analyte $(1.0-200 \mu \mathrm{g} / \mathrm{mL}) .20 \mu \mathrm{L}$ of each solution was injected in to the HPLC system and the peak area of the chromatogram obtained was noted.
The intra-day precision of the assay method was evaluated by carrying out 9 independent assays of a test sample of Valganciclovir at three concentration levels (10, 20 and 50 $\mu \mathrm{g} / \mathrm{mL})(\mathrm{n}=3)$ against a qualified reference standard. The $\%$ RSD of three obtained assay values at three different concentration levels was calculated. The interday precision study was performed on three different days i.e. day 1 , day 2 and day 3 at three different concentration levels (10, 20 and $50 \mu \mathrm{g} / \mathrm{mL}$ ) and each value is the average of three determinations $(\mathrm{n}=3)$. The $\% \mathrm{RSD}$ of three obtained assay values on three different days was calculated.

\section{Accuracy}

The accuracy of the assay method was evaluated in triplicate at three concentration levels (80, 100 and 120\%), and the percentage recoveries were calculated. Standard addition and recovery experiments were conducted to determine the accuracy of the method for the quantification of Valganciclovir in the drug product. The study was carried out in triplicate at 18,20 and $22 \mu \mathrm{g} / \mathrm{mL}$. The percentage recovery in each case was calculated.

\section{Sensitivity/Limit of quantification (LOQ) and limit of detection (LOD)}

The limit of quantification (LOQ) and limit of detection (LOD) were based on the standard deviation of the response and the slope of the constructed calibration curve $(n=3)$, as described in International Conference on Harmonization guidelines Q2 (R1) ${ }^{12}$. Sensitivity of the method was established with respect to limit of detection (LOD) and LOQ for Valganciclovir. LOD and LOQ were established by slope method as mentioned below. LOD and LOQ were experimentally verified by injecting six replicate injections of each impurity at the concentration obtained from the above formula.

$$
\begin{aligned}
& \text { LOD }=\frac{3.3 \times \text { standard deviation of y-intercept }}{\text { Slope of the calibration curve }} \\
& \text { LOQ }=\frac{10 \times \text { standard deviation of y-intercept }}{\text { Slope of the calibration curve }}
\end{aligned}
$$

\section{Robustness}

The robustness of the assay method was established by introducing small changes in the HPLC conditions which included wavelength (252 and $256 \mathrm{~nm})$, percentage of methanol in the mobile phase (53 and 57) and flow rate ( 0.7 and $0.9 \mathrm{~mL} / \mathrm{min})$. Robustness of the method was studied using six replicates at a concentration level of 20 $\mu \mathrm{g} / \mathrm{mL}$ of Valganciclovir.

\section{RESULTS AND DISCUSSION}

A reversed-phase liquid chromatographic technique was developed to quantitate Valganciclovir in pharmaceutical dosage forms. No stability indicating liquid chromatographic method was reported earlier in the literature. A detailed comparative study of the previously published methods with the present method was given in Table

\section{Precision}


Table 1 Comparison of the performance characteristics of the present method with the published methods

\begin{tabular}{|c|c|c|c|c|c|}
\hline $\begin{array}{l}\text { S. } \\
\text { No. }\end{array}$ & Method /Reagent & $\begin{array}{c}\lambda \\
(\mathrm{nm})\end{array}$ & $\begin{array}{r}\text { Linearity } \\
(\mu \mathrm{g} / \mathrm{mL})\end{array}$ & Remarks & Ref \\
\hline 1. & $\begin{array}{l}\text { (HPLC) } \\
\text { Acetonitrile:methanol: } \mathrm{KH}_{2} \mathrm{PO}_{4}(\mathrm{pH} 5.0) \\
(40: 20: 40, \mathrm{v} / \mathrm{v})\end{array}$ & 255 & $10-3000$ & human serum & 2 \\
\hline 2. & $\begin{array}{c}\text { (HPLC) } \\
\text { Acetonitrile: Potassium dihydrogen phosphate } \\
(\mathrm{pH} 4.0)(60: 40, \mathrm{v} / \mathrm{v})\end{array}$ & 254 & $0.01-60$ & Low linearity range & 3 \\
\hline 3 & $\begin{array}{c}\text { (HPLC) } \\
\text { n-Hexane: ethanol: isopropyl alcohol: tri-fluoro } \\
\text { acetic acid (98: 1.5: } 0.5: 0.1, \mathrm{v} / \mathrm{v} / \mathrm{v} / \mathrm{v})\end{array}$ & 215 & - & Chiral purity & 4 \\
\hline 4 & $\begin{array}{c}\text { (Spectrophotometry) } \\
\text { Methanol }\end{array}$ & 254 & $5-39$ & Very narrow linearity range & 5 \\
\hline 5 & LC/MS & - & - & Human plasma & 6 \\
\hline 6 & LC/MS/MS & - & - & $\begin{array}{c}\text { Plasma and its active } \\
\text { metabolites }\end{array}$ & 7 \\
\hline 7 & LC/MS/MS & - & - & $\begin{array}{c}\text { Plasma and its active } \\
\text { metabolites }\end{array}$ & 8 \\
\hline 8 & $\begin{array}{c}\text { (HPLC) } \\
\text { Methanol: trifluoro acetic acid (Gradient mode) }\end{array}$ & - & - & $\begin{array}{l}\text { Impurity profile and related } \\
\text { substances }\end{array}$ & 9 \\
\hline 9 & $\begin{array}{c}\text { (HPLC) } \\
\text { Methanol: water:glacial acetic acid } \\
(55: 44: 0.1, \mathrm{v} / \mathrm{v})\end{array}$ & 254 & $1.00-200$ & $\begin{array}{l}\text { Stability indicating method } \\
\text { Wide linearity range } \\
\text { (PDA detector) }\end{array}$ & $\begin{array}{c}\text { Present } \\
\text { work }\end{array}$ \\
\hline
\end{tabular}

A reversed-phase chromatographic technique was developed for the determination of Valganciclovir in tablets. Satisfactory resolution was achieved with use of a mixture of methanol, water and glacial acetic acid $(55: 45: 0.1, \mathrm{v} / \mathrm{v})$ with UV detection at $254 \mathrm{~nm}$ (Figure 2). C8 and C18 columns were first evaluated as stationary phase for the separation of Valganciclovir but C18 column was adopted for the analysis as it has provided a better separation of the analytes.

\section{HPLC Method Development and Optimization}

Initially the stressed samples were analyzed using a mobile phase consisting of water: acetonitrile $(70: 30, \mathrm{v} / \mathrm{v})$ at a flow rate of $1.0 \mathrm{~mL} / \mathrm{min}$. Under these conditions, the resolution and peak symmetry were not satisfactory, so the mobile phase was changed to methanol: water $(40: 60, \mathrm{v} / \mathrm{v})$ with a flow rate of $1.0 \mathrm{~mL} / \mathrm{min}$ under which peak tailing was observed.

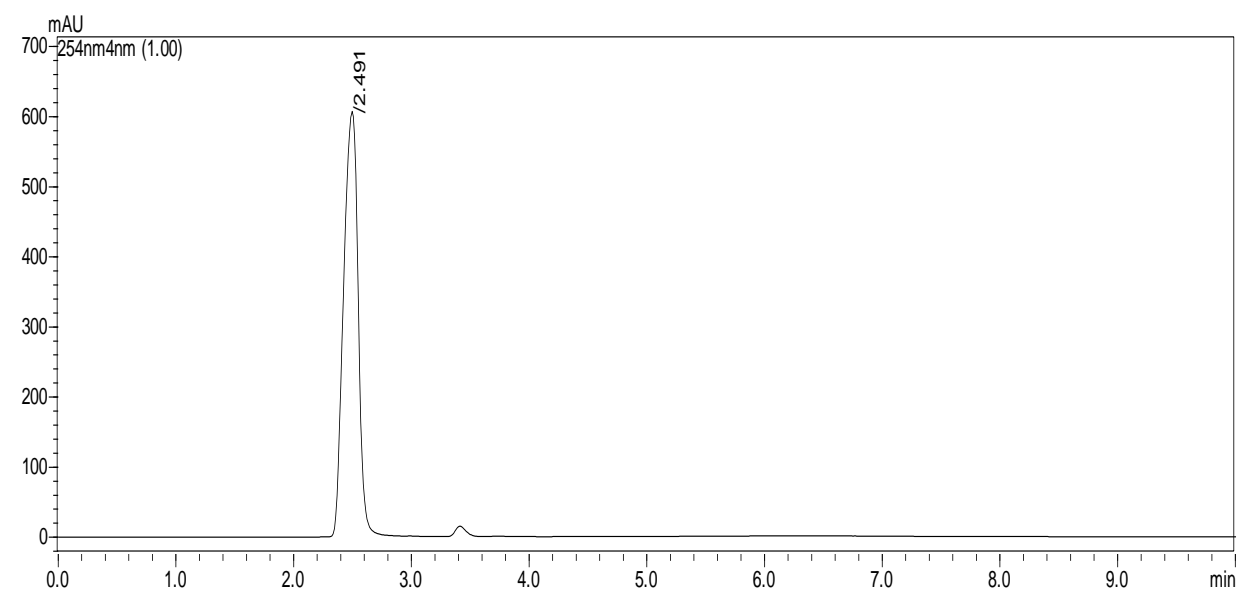

Figure 2: Typical Chromatogram of Valganciclovir $(100 \mu \mathrm{g} / \mathrm{mL})$

Finally the mobile phase containing methanol: water: glacial acetic acid (45:55: $0.1, \mathrm{v} / \mathrm{v})$ was chosen as the best chromatographic response for the entire study where a sharp peak was observed around 2.5 mins.

\section{Method Validation}

\section{Linearity}

The calibration curve for Valganciclovir was linear over the concentration range of $1.00-200 \mu \mathrm{g} / \mathrm{mL}$. The data for the peak area of the drug in corresponds to the concentration was treated by linear regression analysis (Table 2) and the regression equation for the calibration 
curve (Figure 3) was found to be $\mathrm{y}=50968 \mathrm{x}+86374$ with correlation coefficient of 0.999 .

\section{Limit of Detection and Limit of Quantification}

The LOQ and LOD were found to be $0.8641 \mu \mathrm{g} / \mathrm{mL}$ and $0.2813 \mu \mathrm{g} / \mathrm{mL}$ respectively.

Table 2: Linearity of Valganciclovir

\begin{tabular}{|c|c|c|}
\hline Conc. $(\mu \mathrm{g} / \mathrm{mL})$ & *Mean peak area \pm SD & RSD $(\%)$ \\
\hline 1 & $124567 \pm 361.24$ & 0.29 \\
\hline 5 & $417982 \pm 1379.34$ & 0.33 \\
\hline 10 & $517992 \pm 2538.16$ & 0.49 \\
\hline 20 & $1195971 \pm 7893.41$ & 0.66 \\
\hline 50 & $2645833 \pm 14022.31$ & 0.53 \\
\hline 100 & $5177187 \pm 19673.31$ & 0.38 \\
\hline 150 & $7778901 \pm 63786.99$ & 0.52 \\
\hline 200 & $10237618 \pm 38902.95$ & 0.38 \\
\hline
\end{tabular}

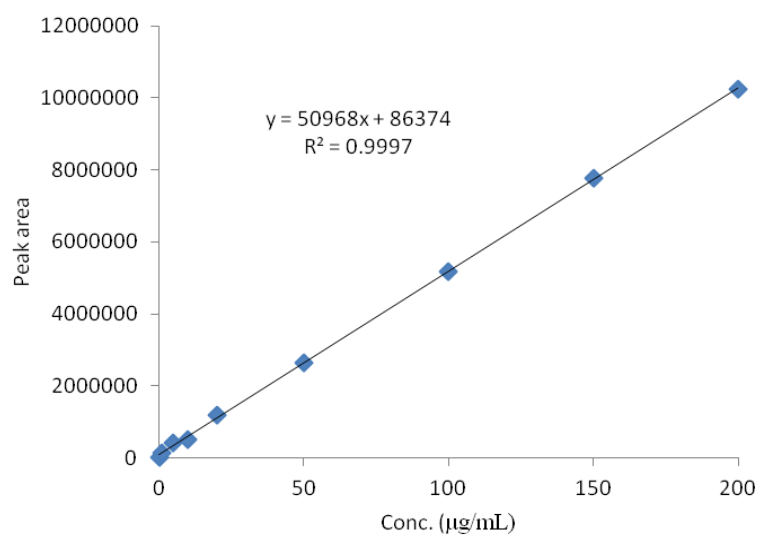

Figure 3: Calibration Curve of Valganciclovir

\section{Precision}

The inter-day precision was calculated by assaying three samples of each at three different concentration levels (10, 20 and $50 \mu \mathrm{g} / \mathrm{mL}$ ) on three different days. The \% RSD range was obtained as $0.28-0.61$ and $0.35-0.89$ for intraday and inter-day precision studies respectively (Table 3).

\section{Accuracy}

The method accuracy was proven by the recovery test. A known amount of Valganciclovir standard $(10 \mu \mathrm{g} / \mathrm{mL})$ was added to aliquots of samples solutions and then diluted to yield total concentrations as 18,20 and $22 \mu \mathrm{g} / \mathrm{mL}$ as described in Table 3. The assay was repeated over 3 consecutive days. The resultant \% RSD was 0.29-0.92 $(<2.0 \%)$ with a recovery 98.78-98.82 \%.

Table 3: Precision and accuracy study of Valganciclovir

\begin{tabular}{|c|c|c|c|}
\hline \multirow{2}{*}{$\begin{array}{c}\text { Conc. } \\
(\mu \mathrm{g} / \mathrm{mL})\end{array}$} & Intra-day precision & Inter-day precision \\
\cline { 2 - 4 } & *Mean peak area $\pm \mathrm{SD}(\% \mathrm{RSD})$ & *Mean peak area \pm SD $(\% \mathrm{RSD})$ \\
\hline 10 & $517987 \pm 1450.36(0.28)$ & $517889 \pm 1812.6115(0.35)$ \\
\hline 20 & $1195891 \pm 5859.86(0.49)$ & $2645032 \pm 23540.78(0.89)$ \\
\hline 50 & $2644929 \pm 16134.06(0.61)$ & $*$ Drug found $(\mu \mathrm{g} / \mathrm{mL})$ & $\%$ Recovery* \\
\hline \multicolumn{3}{|c|}{ Accuracy } \\
\hline $\begin{array}{c}\text { Conc. } \\
(\mu \mathrm{g} / \mathrm{mL})\end{array}$ & $*$ Mean peak area $\pm \mathrm{SD}(\% \mathrm{RSD})$ & 17.78 & 98.79 \\
\hline 18 & $698456.00 \pm 20255.24(0.29)$ & 19.96 & 99.82 \\
\hline 20 & $1088191.00 \pm 7073.24(0.65)$ & 21.73 & 98.78 \\
\hline 22 & $1745889.00 \pm 16062.17(0.92)$ & & \\
\hline
\end{tabular}

*Mean of three replicates

\section{Robustness}

The robustness of an analytical procedure refers to its ability to remain unaffected by small and deliberate variations in method parameters and provides an indication of its reliability for routine analysis ${ }^{12}$. The robustness of the method was evaluated by assaying the same sample under different analytical conditions deliberately changing from the original condition. The detection wavelength was set at 252 and $256 \mathrm{~nm}( \pm 2 \mathrm{~nm})$, the ratio of percentage of water: methanol in the mobile phase was applied as 53:47 and 57:43 $( \pm 2 \%, \mathrm{v} / \mathrm{v})$, the flow rate was set at 0.7 and 0.9 $\mathrm{mL} / \mathrm{min}( \pm 0.1 \mathrm{~mL} / \mathrm{min})$. The results obtained from assay of the test solutions were not affected by varying the conditions and were in accordance with the results for original conditions. The \% RSD value of assay determined 
for the same sample under original conditions and the developed method was robust (Table 4). robustness conditions was less than $2.0 \%$ indicating that

Table 4: Robustness study of Valganciclovir

\begin{tabular}{|c|c|c|c|c|}
\hline Parameter & Condition & $\begin{array}{c}\text { *Mean peak } \\
\text { area }\end{array}$ & $\begin{array}{c}* \text { Mean } \pm \text { SD } \\
(\% \text { RSD })\end{array}$ & $\%$ Assay* \\
\hline \multirow{3}{*}{ Flow rate $(\mathrm{mL} / \mathrm{min})$} & 0.7 & 519835 & \multirow{3}{*}{$\begin{array}{c}517805.33 \pm 3003.27 \\
(0.58)\end{array}$} & \multirow[b]{3}{*}{99.98} \\
\hline & 0.8 & 517992 & & \\
\hline & 0.9 & 515589 & & \\
\hline \multirow{3}{*}{ Detection wavelength (nm) } & 252 & 510881 & \multirow{3}{*}{$\begin{array}{c}512087.33 \pm 3943.07 \\
(0.77)\end{array}$} & \multirow[b]{3}{*}{99.80} \\
\hline & 254 & 517992 & & \\
\hline & 256 & 507389 & & \\
\hline \multirow{3}{*}{$\begin{array}{l}\text { Mobile phase composition } \\
\text { (Water: Methanol) (v/v) }\end{array}$} & $53: 47$ & 510831 & \multirow{3}{*}{$\begin{array}{c}516255.00 \pm 4956.04 \\
(0.96)\end{array}$} & \multirow[b]{3}{*}{98.94} \\
\hline & $55: 45$ & 517992 & & \\
\hline & $57: 43$ & 519942 & & \\
\hline
\end{tabular}

\section{Analysis of Commercial Formulations (Tablets)}

The proposed method was applied to the determination of Valganciclovir tablets and VALCYT ${ }^{\circledR}$ and the result of these assays yielded $99.81 \%$ respectively with RSD $<2.0$ $\%$. The result of the assay (Table 5) indicates that the method is selective for the assay of Valganciclovir without interference from the excipients used in these tablets. The typical chromatograms for Valganciclovir obtained from the extracted marketed formulations were shown in Figure

Table 5: Analysis of Valganciclovir commercial formulation (Tablets)

\begin{tabular}{|c|c|c|c|c|}
\hline $\begin{array}{c}\text { Sample } \\
\text { No. }\end{array}$ & Formulation & Labeled claim $(\mathrm{mg})$ & $\begin{array}{c}* \text { Amount found } \\
(\mathrm{mg})\end{array}$ & $*$ Recovery $(\%)$ \\
\hline 1 & VALCYT $^{\circledR}$ & 450 & 388.41 & 99.81 \\
\hline
\end{tabular}

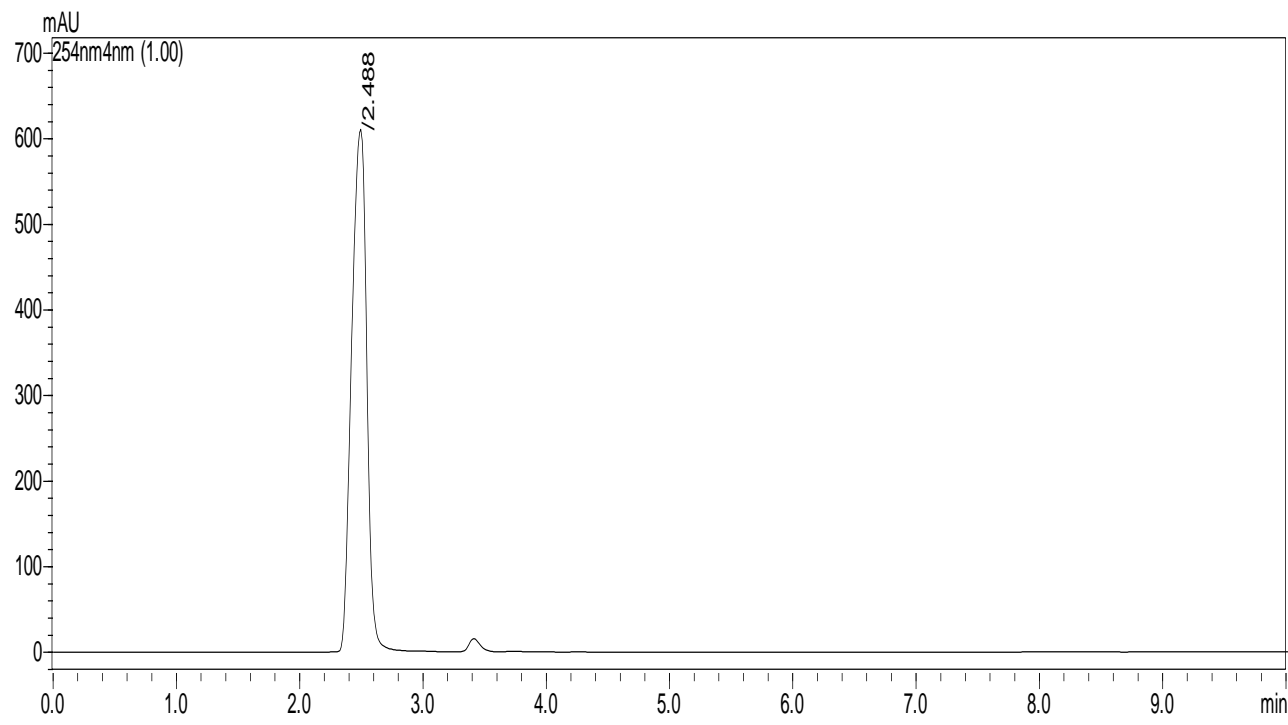

Figure 4: Typical Chromatogram of Valganciclovir $(100 \mu \mathrm{g} / \mathrm{mL})$ VALCYT $^{\circledR}(450 \mathrm{mg})$

\section{Selectivity/Specificity}

The specificity of the developed method was determined by injecting sample solutions $(100 \mu \mathrm{g} / \mathrm{mL})$ which were prepared by forcibly degrading under such stress conditions as heat, light, oxidative agent, acid and base under the proposed chromatographic conditions. The stability indicating capability of the method was established from the separation of Valganciclovir peak from the degraded samples derived from the software. The degradation of Valganciclovir was found to be very similar for both the tablets and standard.

\section{Solution Stability and Mobile Phase Stability}

The \%RSD of the assay of Valganciclovir from the solution stability and mobile phase stability experiments was within $2 \%$. The results of the solution and mobile phase stability experiments confirm that the sample 
solutions and mobile phase used during the assays were stable up to $48 \mathrm{~h}$ at room temperature and up to 3 months at $4^{\circ} \mathrm{C}$.

\section{Forced Degradation Studies}

Valganciclovir standard and tablet powder was found to be quite stable under dry heat conditions. Typical chromatograms obtained following the assay of stressed samples are shown in Figure 5 (A-E).

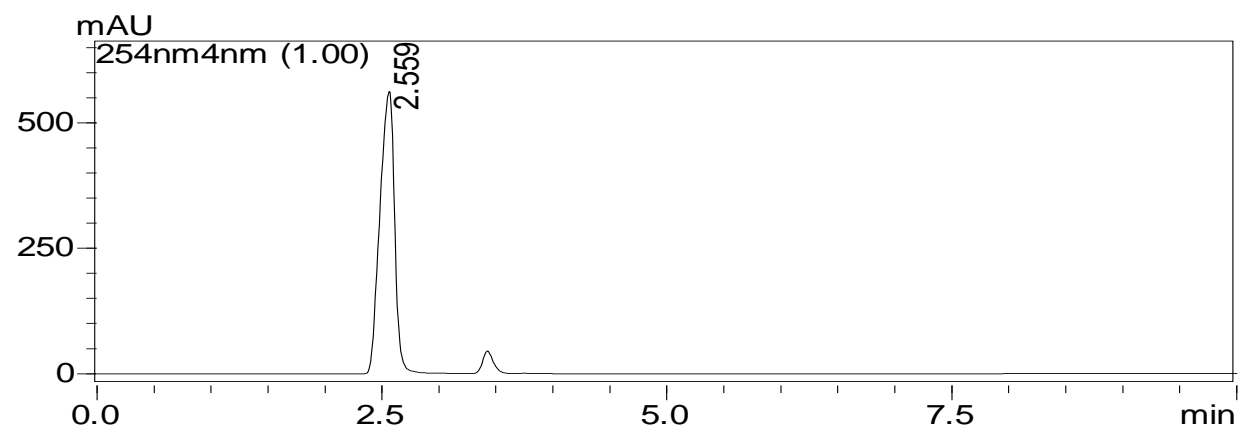

[A]

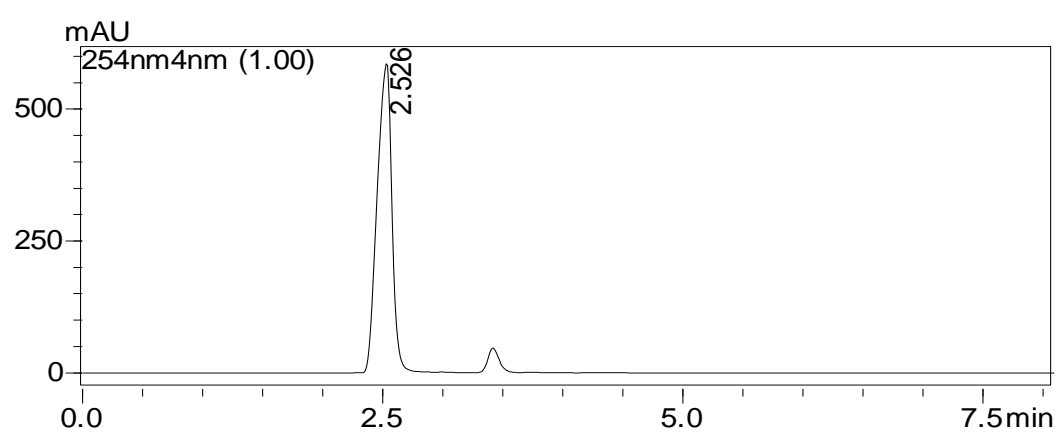

[B]

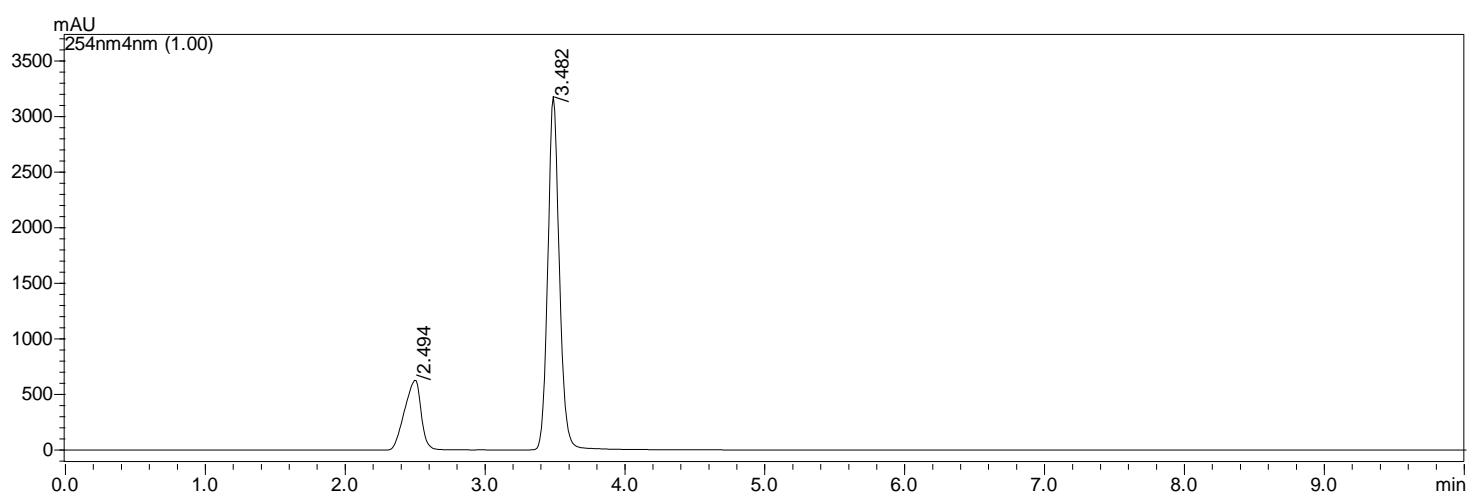

[C]

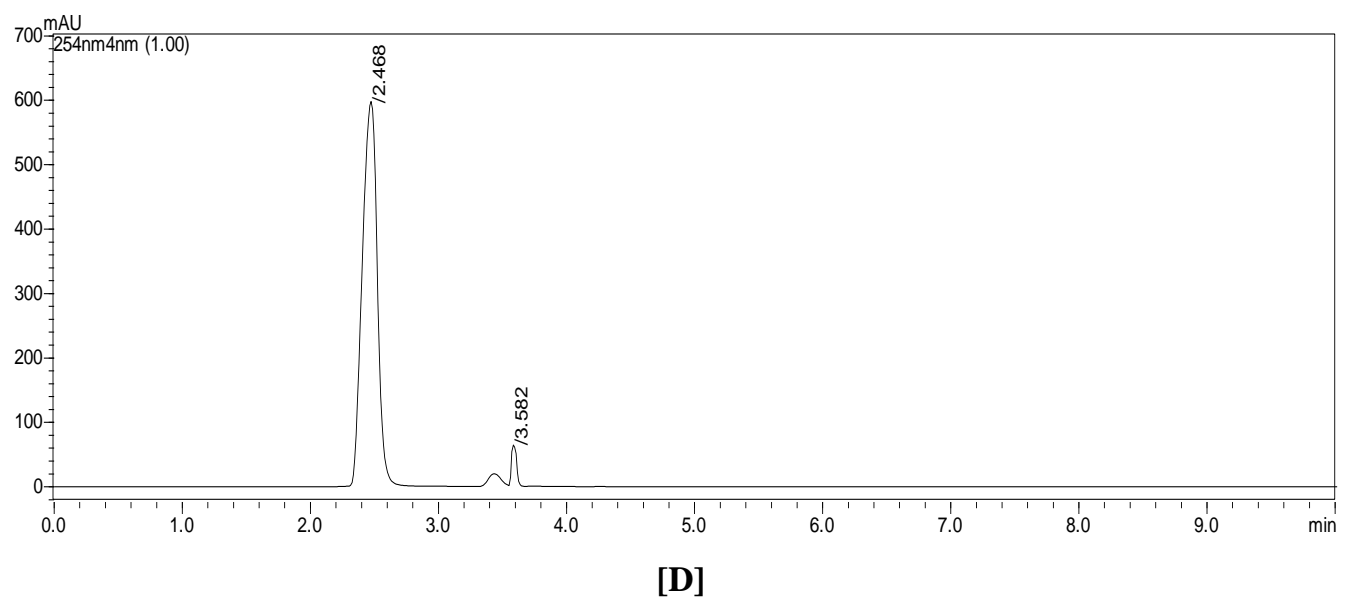

Figure 5: Typical Chromatograms of Valganciclovir $(100 \mu \mathrm{g} / \mathrm{mL}))$ on Acidic [A], Alkaline [B], Oxidative [C] and Thermal [D] Degradations 
A very slight decomposition was seen on exposure of Valganciclovir drug solution to acidic (3.23), alkaline (3.21) and oxidation (1.25). During the oxidative degradation a major degradants were observed at 3.482 mins without interfering the elution of drug peak. Valganciclovir has undergone thermal degradation (1.11) very slightly and Table 6 summarises the data of degradation studies.

\section{System Suitability}

The system suitability test was performed to ensure that the complete testing system was suitable for the intended application. The parameters measured were peak area, retention time, tailing factor, capacity factor and theoretical plates. In all measurements the peak area varied less than $2.0 \%$, the average retention time was $5.5 \pm 0.05$ minutes. The capacity factor was more than 2 , theoretical plates were more than 2000 and tailing factor was less than 1.5 for the Valganciclovir peak (Table 6).

Table 6: Forced degradation studies of Valganciclovir

\begin{tabular}{|c|c|c|c|c|c|}
\hline Stress conditions & $\begin{array}{c}* \text { Mean peak } \\
\text { area }\end{array}$ & $\begin{array}{c}\text { \% Drug } \\
\text { recovered }\end{array}$ & $\begin{array}{c}\text { \% Drug } \\
\text { decomposed }\end{array}$ & $\begin{array}{c}\text { Theoretical } \\
\text { plates }\end{array}$ & Tailing factor \\
\hline Standard Drug & 5195753 & 100 & - & 4261.187 & 1.012 \\
\hline Acidic degradation & 5081089 & 96.77 & 3.23 & 4169.378 & 1.011 \\
\hline Alkaline degradation & 5075503 & 96.79 & 3.21 & 4087.112 & 1.013 \\
\hline Oxidative degradation & 4657716 & 98.75 & 1.25 & 4066.286 & 1.004 \\
\hline Thermal degradation & 5177187 & 98.89 & 1.11 & 4031.448 & 1.118 \\
\hline
\end{tabular}

\section{CONCLUSION}

The proposed stability-indicating HPLC method was validated as per ICH guidelines and can be applied for the determination of Valganciclovir in pharmaceutical dosage forms. The method was found to be accurate, precise, robust and specific as the drug peak did not interfere with the extra peaks aroused during the forced degradation studies. At the same time the chromatographic elution step is undertaken in a short time $(<3 \mathrm{~min})$. No interference from any components of pharmaceutical dosage form can be successfully applied to perform accelerated stability studies of Valganciclovir formulations.

\section{ACKNOWLEDGEMENTS}

The authors are grateful of M/S GITAM University, Visakhapatnam, India for providing research facilities and also to Roche, India for providing the gift samples of the drug.

\section{REFERENCES}

1. Neil M.J. O', The Merck Index, $14^{\text {th }}$ ed., Whitehouse Station, NJ: Merck Research Laboratories Division of Merck and Co., Inc.; 2006.

2. Dogan-Topal B., Uslu B. and Ozkan S. A., "Development and validation of an rp-hplc method for determination of Valganciclovir in human serum and tablets" Chromatographia 2007, 66, S97-S101.

3. Manikaya Rao T, Prabhakar T., Girija Sankar G. and Jyothi N., "Development and validation of new stability indicating hplc method for determination of Valganciclovir in tablet dosage form" Int. J. Pharm. Sci. 2012, 2(4), 101-104.

4. Surya Naga Malleswara Rao Ch., Srinivas K., Suryanarayana M. V., Madhavan P. and Mukkanti K., "Validated LC Method for the determination of chiral purity of (S)-2-azido-3methylbutanoic acid: A key raw material of Valganciclovir hydrochloride" J. Chem. Pharm. Res. 2011, 3(4), 22-28.

5. Awen B.Z., Dasari V., Chandu B.R., Khagga M., Katakam P., "New simple UV spectrophotometric method for the estimation of Valganciclovir in bulk and its formulation" Int. J. Pharm. Studies and Res. 2011, 2(1), 55-58.

6. Onkar Singh, Saurabh Saxena, Sanjeev Mishra, Arshad Khuroo, Tausif Monif, "Determination of Valganciclovir and ganciclovir in human plasma by liquid chromatography tandem mass

spectrometric detection”, Clinical Biochem. 2011, 44, (10-11), 907-915.

7. Hong-Rong Xu, Xue-Ning Li, Wei-Li Chen, Gang-Yi Liu, NanNan Chu, Chen Yu, "A sensitive assay for simultaneous determination of plasma concentrations of Valganciclovir and its active metabolite ganciclovir by LC/MS/MS" 2007, J. Chromatogr. B, 848(2), 329-334.

8. Heinig K., Wirz T., Gajate-Perez A., Belli S., "A sensitive assay for simultaneous determination of plasma concentrations of Valganciclovir and its active metabolite ganciclovir by LC/MS/MS" J. Chromatogr. B 2011, 879, 436-442.

9. Suresh Kumar R., Hariram B., Divya G., Srinivasu M.K., Katkam Srinivas, Rajeshwar Reddy Sagyam, "Development of a RP-LC method for a diastereomeric drug Valganciclovir hydrochloride by enhanced approach" J. Pharm. Biomed. Anal. 2012, 70, 101-110.

10. Stefanidis D., Brandl M., Reactivity of Valganciclovir in aqueous solution, Drug Dev. Ind. Pharm. 31 (2005) 879-884.

11. ICH Stability testing of New Drug Substances and Products Q1A (R2), International Conference on Harmonization, Geneva, Switzerland, (2003).

12. ICH Validation of analytical procedures: Text and methodology Q2 (R1), International Conference on Harmonization, Geneva, Switzerland, (2005). 